\title{
The Prevalence of Commonly Encountered Parasites in Sheep in Iğdır Province, Turkey
}

\author{
Fatma Ertaş ${ }^{1, a, *}$, Ayşe Sona Karakuş ${ }^{2, b}$, Adnan Ayan ${ }^{3, c}$ \\ ${ }^{1}$ Department of Medical Services and Techniques, Tuzluca Vocational School, I $\breve{g} d ı r$ University, 76000 Iğdır, Turkey \\ ${ }^{2}$ Department of Parasitology, Faculty of Veterinary Medicine, Van Yüzüncü Yll University, 65040 Van, Turkey \\ ${ }^{3}$ Department of Genetics, Faculty of Veterinary Medicine, Van Yüzüncü Yll University, 65040 Van, Turkey
}

*Corresponding author

\begin{tabular}{|c|c|}
\hline A R T I C L E I N F O & A B S T R A C T \\
\hline $\begin{array}{l}\text { Keywords: } \\
\text { Iğdır province } \\
\text { Parasitic disease } \\
\text { Prevalence } \\
\text { Sheep }\end{array}$ & $\begin{array}{l}\text { Sheep farming is an important segment of the livestock sector in Turkey. However, low meat, milk, } \\
\text { leather and wool production due to various parasitic diseases has adversely affected this sector. This } \\
\text { study was carried out by using stool and tissue samples collected from } 300 \text { sheep registered with } \\
\text { the Provincial Directorate of Agriculture and Forestry in Iğdir, Turkey. Stool samples were } \\
\text { collected using native, flotation and sedimentation methods to diagnose common parasites. In } \\
\text { addition, parasitic diagnoses were strengthened with the migration paths of parasites and the } \\
\text { presence of cysts as a result of macroscopic examination of the liver and lungs of sheep slaughtered } \\
\text { in the slaughterhouse. From the data obtained, the prevalence and material damage and loss of } \\
\text { workforce of parasites were determined using appropriate statistical programs. Fascioliasis } 16.7 \% \text {, } \\
\text { Nematodirosis } 20 \% \text { Echinococcosis } 29 \% \text { Dicrocoeliasis } 32 \% \text { varied. It was concluded that the } \\
\text { parasite population is high in sheep in Iğdir province, Turkey. Accordingly, attention was drawn to } \\
\text { the issue of necessary protection and controls. }\end{array}$ \\
\hline
\end{tabular}

Turkey

\section{Introduction}

The sheep are preferred animals by the farmers as they are small, easy to control, could be reared in mountainous areas by using low grade pastures with low cost. The sheep are commonly raised in various centuries for meat, milk, leather and wool production, which further used and processed for making other miscellaneous local products for the domestic market (Gül and Örnek, 2018). Sheep farming is an important segment of the livestock sector (Bhowmik et al., 2020) and is quite common in the Eastern Anatolia region of Turkey. However, parasitic diseases, which are an important factor in the production and yield losses obtained from this sector, cause great losses in meat, milk, leather and wool production (Der, et al., 1994; Değer and Biçek, 2005; Acıöz, 2019). Turkey is a geographical area suitable for parasitic life as it is a country where different climate types are seen regionally (Taş, 1997; Değer and Biçek, 2005). Parasitic outbreaks due to endoparasites in domestic animals are very common in Turkey, which cause serious damage regional animal husbandry industry and ultimately to the country's economy (Deger and Biçek, 2005). Protozoan, trematode and cestode infections that develop in the liver have a remarkable place in liver pathology (Metin, 2011; Kircalı Sevimli, 2013). Fascioliasis disease caused by chronic trematode invasion including Fasciola hepatica and Fasciola gigantica of Fasciolidae family in the liver and bile ducts of sheep is a common worldwide (Scott, 2009; Metin, 2011; Kircalı Sevimli, 2013). It causes hepatitis and peritonitis especially on the visceral surface of the liver (Stalker and Hayes, 2007; Scott, 2009). The trematodes penetrating the liver capsule create necrotic bleeding tunnels and coagulation necrosis in the parenchyma (Toparlak and Tüzer, 1999; Metin, 2011). The pulpy content formed in the bile ducts contains bile, pus, exfoliated cells, tissue debris, trematode clumps and egg masses and causes bile retention (Stalker and Hayes, 2007; Metin, 2011).

The dicrocoeliosis is a helminthosis disease caused by parasitism in the bile ducts and gallbladder of ruminants and many other animal species, including humans (Gürelli, 2017; Erdoğan et al., 2019). In the biological life cycle of Dicrocoelium, land snails serve as the first intermediate 
host and ants as the second intermediate host. Sporocyst and larval stages of cercaria live in the hepatopancreatic abdomen of land snails, and metacercariae larval stages in the abdomen and brains of ants. This parasitic disease, which is especially common in ruminant animals, can cause weight loss and decreased milk production in animals by affecting the liver (Gürelli, 2017). Sheep are not immune to this parasite, and as a result of continuous metacercariae ingestion, parasites can increase in number up to 50,000 (Toparlak and Tüzer, 1999). Dicrocoeliosis records are increasing due to the expansion of arid habitats and the resistance of the parasite to anthelmintic drugs (Gürelli, 2017).

The hydatidosis caused by Echinococcus spp. is a common zoonotic disease in the world. The mature parasite lives in dogs, however, the hydatid cysts, which are its larvae, can be found in the organs especially liver and lung of many intermediate hosts, including humans, (Metin, 2011; Kırcalı Sevimli, 2013). Hydatid cyst disease (HSC) is a parasitic disease frequently observed in countries where agriculture and animal husbandry are common, and its incidence varies between 1 and 150 per 100,000. It was determined that 171 $(0.88 \%)$ of a total of 14789 HCI cases detected between 2001 and 2005 were died in Turkey. It has been reported that lung cysts can be single in $72 \%$ and multiple in $28 \%$ cases (Korcan Tilkan et al., 2018).

The gastrointestinal nematode infestations are one of the most important reasons closely related to intensive sheep breeding. Nematodirosis, which affects young lambs, causes great losses in the late spring/early summer period (Yeşildere and Deprem, 2007). Infestations range from acute illnesses to chronic patients with sudden death. The nematodirus diarrhea in young lambs, can lead to low productivity and weight loss.

In the light of this information, it is aimed to determine the prevalence of parasites that are frequently encountered in Iğdır Province, to determine the economic losses that occur in this context, to lose work force and to raise awareness about it.

In addition, it is thought that it will contribute to further studies in the prevention of parasitic diseases with the data we can present as a result of the study.

\section{Statistical Analysis}

Student's t-test was used for statistical analysis. Data were given as arithmetic mean \pm standard deviation $(\mathrm{X} \pm \mathrm{SX})$. Statistical significance level was accepted as $\mathrm{P}<0.05$ in calculations and SPSS 20.0 statistical package program was used for calculations (SPSS 10.0 for Windows).

\section{Materials and Methods}

The study was carried out by using stool and tissue samples collected from 300 female sheep registered with the Provincial Directorate of Agriculture and Forestry in Iğdır Province and its districts.

\section{Examination of Animals}

General examination was done before slaughter. Lymph nodes and eye mucosa were checked. Respiration was examined with a heart stethoscope. Body temperature was measured with a digital thermometer. The results have been recorded.
Common parasites were diagnosed by using native, flotation and sedimentation methods of stool samples. In addition, parasitic diagnoses were strengthened by the presence of cysts and migration routes of parasites, which were seen as a result of macroscopic examinations of the liver and lungs of the sheep slaughtered in the slaughterhouse. In native, flotation and sedimentation methods, samples of eggs or cysts or cysts of parasites under the microscope in stool samples were considered positive. In addition, liver and bile were examined in the slaughterhouse. As a result, adult parasites, if any, were detected. For the echinococcosis diagnosis the fluid was drawn from the cysts detected macroscopically in the livers of sheep with an injector. The fluid was then examined under the microscope, and samples with protoscolex were considered positive.

\section{Results and Discussion}

\section{Clinical Results}

Anorexia, weakness and anemia were determined in all sheep included in the study and positive for parasites, while edema under the chin was observed especially in sheep with fasciolosis. Internal parasite eggs were detected in the stool examination. Parasitic agents were observed in the internal organs of the sheep slaughtered in the slaughterhouse and included in the study.

The results are presented in Table 1 shows that 50 (16.7\%) sheep were positive for Fasciola species, 87 (29\%) positive for Echinococcus species, 96 (32\%) positive for Dicrocoelium dendriticum and 60 (20\%) positive for Nematodirus spp.

Endoparasites cause important disorders in host animals by causing malnutrition and the organ destruction. Endoparasitic diseases cause poor reproductive performance, growth retardation, and loss of quality and quantity in animal products such as meat, milk and fleece (High et al. 2007). In our study, anamnesis information was obtained by Yüksek, et al. (2007) was similar to that stated. There was also anemia as a clinical sign.

Liver fluke, Fasciola hepatica, is a common zoonotic parasite (Mokhtarian, et al. 2018; Shi, et al. 2020). This parasite causes diseases in animals such as sheep, goats, cattle and buffalo (Shi, et al. 2020). The prevalence of Fasciola spp. varies between $0.8 \%$ and $72 \%$ in sheep in Turkey (Çaya, 2012; Sevimli, 2013; Kaplan et al, 2014, Firat and Alpak, 2019). In addition, in the study conducted by Gül (2007) in the Iğdır region, reported $17.22 \%$ Fasciola spp. In our study, Fasciola spp. the incidence rate is $16.7 \%$. According to these values, it was concluded that there was no significant difference proportionally.

Parasitic diseases caused by liver trematodes have an important place among many parasitic infections that cause decreased productivity in animals. Among the liver trematodes, D. dendriticum settles in the liver of ruminants and causes weight loss and decreased milk yield. (Çınar, et al. 2018).

Dicrocoelium spp. It has been reported between $1.1 \%$ and $58.9 \%$ in different studies conducted in Turkey (Çaya, 2012; Cute, 2013; Kaplan et al, 2014, Firat and Alpak, 2019). Our study parallels this, Dicrocoelium spp. (32\%) was found. It was found to be similar according to the study of Gül (2007). Echinococcus spp. Hydatid Cyst is a common zoonotic disease in the world (Metin, 2011; Kurcalı Kelebek, 2013, Irak, et al. 2018). This disease, 
which is also common in Turkey, poses a health and economic problem (Barış, et al. 1989).

Umur and Aslantaş (1993) found the spread of hydatid cyst in sheep slaughtered in Kars Municipality slaughterhouse to be $48.35 \%$. Toparlak and Gül (1999) reported the spread of hydatidosis as $32.9 \%$ in sheep in the Van old Municipality Slaughterhouse, and Zeybek and Tokay (1990) as 22\% in ruminants slaughtered in Ankara and its districts without any animal discrimination. According to the literature, hydatid cysts were found in
0.6-58.6\% of sheep in Turkey (Cantoray, et al. 1992; Toparlak and Gül, 1999; Dik, et al.1992; Oğuz and Değer, 2013).

In our study, the rate of Echinococcus was found to be $29 \%$. The results were found to be in parallel with these studies. Rates between $0.3 \%$ and $44.9 \%$ were found in Turkey for different species of Nematodirus spp. (Sevimli, 2013; Firat and Aypak, 2019). This study is similar to the stated data, and Nematodirus spp. percentage of incidence; It was determined as $20 \%$.

Table 1. Detected parasite species and infection rates

\begin{tabular}{l|ccc}
\multicolumn{1}{c|}{ Types of parasites } & Positive $\mathrm{n}(\%)$ & Negative $\mathrm{n}(\%)$ & Total $\mathrm{n}(\%)$ \\
\hline Fasciola spp. & $50(\% 16.7)$ & $250(\% 83.3)$ & $300(\% 100)$ \\
Dicrocoelium dendriticum & $96(\% 32)$ & $204(\% 68)$ & $300(\% 100)$ \\
Echinococcus & $87(\% 29)$ & $213(\% 71)$ & $300(\% 100$ \\
Nematodirus spp. & $60(\% 20)$ & $240 \% 80)$ & $300(\% 100)$ \\
\hline
\end{tabular}

\section{Conclusion}

As a conclusion, this research Fascioliosis $16.7 \%$, Nematodiriasis 20\% Echinococcosis 29\% Dicrocoeliasis $32 \%$ were determined statistically. It was concluded that the parasite population is high in sheep in Iğdır province. It was concluded that the parasite population is high in sheep in Iğdır province. Accordingly, attention was drawn to the issue of necessary protection and controls.

It has been clearly demonstrated that helminth infections are particularly common in sheep, one of the animal groups in which we can best observe herd life among farm animals.

\section{References}

Acıöz M. 2019. Isparta'da kesilen sığırlarda distomatozis' in yayılışı. Erciyes Üniversitesi Veteriner Fakültesi Dergisi, 16(2): 136-140.

Barış İ, Şahin A, Bilir N, Kalyoncu AF, Emri AS, Akhan O. 1989. Hidatik Kist Hastalığı ve Türkiye'deki Konumu. Türkiye Akciğer Hastalıklar Vakfı Yayını, No:1. Ankara, Kent Matbaas1.

Bhowmik M, Hossen MA, Mamun MA, Hasıb F, Poddar S, Hossain MA, Alim MA. 2020. Prevalence of Gastrointestinal Parasitic Infections in Sheep and Goats of Sandwip Island, Chattogram, Bangladesh. Van Veterinary Journal, 31(3): 152-157.

Cantoray R, Aytekin H, Güçlü F. 1992. Konya Yöresinde Keçilerde Helmintolojik Araştırmalar. Veterinarium, 3: 27 30.

Deger S, Biçek K. 2005. Van ve Yöresinde Koyunlarda Endoparaziter Fauna Tespiti ve Paraziter İnvazyonların Kontrolü Üzerine Öneriler. Yüzüncü Y1l Üniversitesi Veteriner Fakültesi Dergisi, 16(1): 51-54.

Deger S, Taşçı S, Akgül Y, Alkan İ. 1994. Van ve yöresinde evcil hayvanlarda ektoparaziter dermatitisler. Yüzüncü Y1l Üniversitesi Veteriner Fakültesi Dergisi, 5(1-2): 155-161.

Dik B, Cantoray R, Kandemir E. 1992. Konya Et ve Balık Kombinasında kesilen küçük ve büyükbaş hayvanlarda hidatidozun yayılışı ve ekonomik önemi. Türkiye Parazitoloji Dergisi, 16: 91-92.

Erdoğan H, Gültekin M, Kerem U, Parlatır Y, Ayan A, Erdoğan S, Paşa S. 2020. Evaluation of albendazole treatment on coagulation profile in sheep naturally infected with Dicrocoelium dentriticum. Veterinary Journal of Mehmet Akif Ersoy University, 4(1): 8-13.
Gül S, Örnek H. 2018. Gaziantep İlinde Küçükbaş Hayvan Yetiştiriciliğinin Yapısal Özellikleri I. Koyun Yetiştiriciliği. Mustafa Kemal Üniversitesi Ziraat Fakültesi Dergisi, 23(2): 306-314.

Gül S, Örnek H. 2019. Gaziantep İlinde Küçükbaş Hayvan Yetiştiriciliğinin Yapısal Özellikleri II. Keçi Yetiştiriciliği. Hayvansal Üretim, 60(2): 89-96.

Gürelli G. 2017. Dicrocoeliosis Epidemiyolojisinde Kara Salyangozlarını Önemi. Türkiye Parazitoloji Dergisi, 41: 169-72.

Kurcalı Sevimli F. 2013. Karaciğer ve diğer iç organlarda görülen helmint hastalıkları, Koyun ve Keçilerde Görülen Paraziter Hastalıklar, Bölüm 6, Veteriner Hekimlikte Paraziter hastalıkları, Cilt 2, Ed. M. Ali Özcel, Türkiye Parazitoloji Derneği Yayını, No 24, İzmir.

Korcan Tilkan O, Uysal S, Gökçe M. 2018. Hidatik Kist Hastalığ1, Medical Journal of Western Black Sea, 2: 153-159.

Metin N. 2011. Veteriner Patoloji Bölüm I. Aydın, Tuna Matbaacilik, 82-112.

Mokhtarian K, Meamar AR, Khoshmirsafa M, Razmjou E, Masoori L, Khanmohammadi M, Falak R. 2018. Comparative assessment of recombinant and native immunogenic forms of Fasciola hepatica proteins for serodiagnosis of sheep fasciolosis. Parasitology research, 117(1): 225-232.

Scott RP. 2009. Sheep Medicine. Çeviri Editörleri: Yeşildere T, Deprem O. Koyun Hastalıkları, İstanbul, Nobel Matbaacılı.

Shi H, Li M, Huang X, Yao C, Chen X, Du A, Yang Y. 2020. Development of SYBR Green real-time PCR for diagnosis of fasciolosis in sheep. Veterinary Parasitology, 283: 109-193.

Stalker MJ, Hayes MA. 2007. Liver and biliary system, In Jubb Kennedy and Palmer's Pathology of Domestic Animals, Ed. Maxie MG, 5th ed. Saunders/Elsevier. Philadelphia, 2: 297-388.

Taş Z. 1997. Van belediye mezbahasında kesilen hayvanlarda paraziter fauna tespiti çalışmaları. Yüzüncü Yıl Üniversitesi Sağlık Bilimleri Enstitüsü. Yüksek Lisans Tezi, Van.

Toparlak M, Gül Y. 1999. Van ili Belediye mezbahasında kesilen hayvanlarda hidatidozun yayılışı. Ankara Üniversitesi Veteriner Fakültesi Dergisi, 36: 129-37.

Toparlak M, Tüzer E. 1999. Veteriner Helmintoloji, İstanbul Üniversitesi Veteriner Fakültesi Yayın1, Ders Notu No: 102.

Umur Ş, Aslantaş Ö. 1993. Kars belediye mezbahasrnda kesilen ruminantlarda hidatidozun yayılışı ve ekonomik önemi. Türkiye Parazitoloji Dergisi, 17: 27-34.

Yeşildere T, Deprem O. 2009. Koyun Hastalıkları; Paraziter Hastalıklar, s.303-307Nobel Tıp Kitapevleri Ltd.Şti.

Zeybek H, Tokay A. 1990. Ankara yöresinde evcil ve yabani kanidaelerde Echinococcus türlerinin yayılış1, kist şekillerinin insidansı ve kontrol olanaklarının araştırılması. Etlik Veteriner Mikrobiyoloji Dergisi, 6: 1-19. 